\title{
Effect of different culture systems on the production of foot and mouth disease trivalent vaccine
}

\author{
Amr Ismail Hassan \\ Department of Foot and Mouth Disease, Veterinary Serum and Vaccine Research Institute, Abbasia, Cairo, Egypt. \\ E-mail: Amr Hassanin@hotmail.com \\ Received: 01.09.2015, Revised: 23.11.2015, Accepted: 04.12.2015, Published online: 12-01-2016
}

doi: 10.14202/vetworld.2016.32-37 How to cite this article: Hassan AI (2016) Effect of different culture systems on the production of foot and mouth disease trivalent vaccine, Veterinary World, 9(1): 32-37.

\begin{abstract}
Aim: This study aims to determine the effect of the stationary rawx, roller, and the suspension cell culture systems on the total virus yield infectivity and antigenicity.

Materials and Methods: Three serotypes of foot and mouth disease virus (FMDV) (serotype A, O and SAT-2) were inoculated separately into baby hamster kidney-21 cell line in rawx, roller, and suspension cultivation systems using multiplicity of infection (1:100). Samples were taken from the total virus yield from each system at 15, 18, 21, and 24 h post-inoculation. Testing the total virus yield infectivity through virus titration and antigenicity through estimation of complement fixing titer and $146 \mathrm{~S}$ content and evaluation of the potency of the vaccine prepared from the different cultivation systems were done.

Results: The results showed that the FMDV titer of serotype A, O, and SAT-2 obtained from the roller cultivation system showed the highest level followed by suspension cultivation system then the rawx cultivation system. The FMDV titer showed its highest level at $21 \mathrm{~h}$ post-inoculation in all the cultivation systems and then decline at $24 \mathrm{~h}$ post-inoculation. The antigenicity reached its highest value content at $18 \mathrm{~h}$ post-inoculation either by complement fixation test or by quantifying the $146 \mathrm{~S}$ intact virion. Montanide ISA 206 oil inactivated trivalent vaccines were prepared from the tested serotypes (A Iran O5. O Panasia and SAT-2/EGY/2012) harvested at $18 \mathrm{~h}$ post-inoculation from the 3 culture systems. The results of tracing the antibody response showed that the mean antibody response from the roller cultivation system start its protective antibody titer earlier at 2 weeks post-vaccination (WPV) than the vaccine prepared from the other two cultivation system and the immune protection period lasts longer for $36 \mathrm{WPV}$ for the roller cultivation system vaccine than the other two cultivation systems.
\end{abstract}

Conclusion: The best cultivation system used for the production of FMD vaccine regarding its highest infectivity and antigenicity is the roller system.

Keywords: baby hamster kidney-21 cell culture, foot and mouth disease virus, monolayer tissue culture cells, suspension tissue culture cells.

\section{Introduction}

Foot and mouth disease (FMD) is considered a highly infectious disease of cattle, sheep, goats, and pigs. It also affects wild animals such as buffaloes and deer $[1,2]$. It is characterized by rise in body temperature with saliva drooling from its mouth due to vesicular lesions on the tongue, gums, cheeks, and hard palate. The sick animals also show vesicular lesions in the cleft of feet, at their coronary bands and on teats of the milking animals. The vesicles soon rupture to form ulcerative lesions. There is a significant reduction in milk production, working efficiency and weight gain and abortions in infected animals. There is $100 \%$ morbidity in susceptible animal population and negligible mortality in adults. However, high mortality in a young animal is due to the virus-induced necrotic lesions and myocardial degeneration $[3,4]$.

Copyright: Hassan. Open Access. This article is distributed under the terms of the Creative Commons Attribution 4.0 International License (http://creativecommons.org/licenses/by/4.0/), which permits unrestricted use, distribution, and reproduction in any medium, provided you give appropriate credit to the original author(s) and the source, provide a link to the Creative Commons license, and indicate if changes were made. The Creative Commons Public Domain Dedication waiver (http://creativecommons.org/ publicdomain/zero/1.0/) applies to the data made available in this article, unless otherwise stated.
The etiologic agent of the disease is the FMD virus (FMDV) which has seven serotypes of FMDV have been recognized including $\mathrm{O}$, A, C, SAT-1, SAT-2, SAT-3, and Asia 1 [2]. Although FMD has a low mortality figure, its high morbidity and contagiousness can lead to enormous economic consequences [5].

In Egypt, The type $\mathrm{O}$ was the most prevalent since 1960 [6-8]. Serotype A was introduced to Egypt in 2006 through importation of animals [9]. In addition, FMDV serotype SAT-2 of FMDV was introduced to Egypt in 2012 [10]. In Egypt and many other countries, the live animal's importation is considered as the main risk factor in many old and new outbreaks of FMD. The effective vaccination of susceptible animals is considered to be the corner stone to eliminate the disease in endemic areas for controlling the FMD in animals [11].

The control of FMD by animal vaccination was effective in limiting the spread of FMD [12]. Such control is dependent on the potency, efficacy, and specificity of the produced vaccine which is related directly on the infectivity and antigenicity of the vaccinal FMDV serotypes used in the vaccine.

FMDV grow well on baby hamster kidney (BHK)-21 cell line enabling large-scale production 
of antigen with good antigenicity. It has also been reported that with subsequent cultivation in BHK21 clone 13 cell line, the titer of FMDV increased. Furthermore, the susceptibility and infectivity titer of BHK-21 is higher than IBRS-2 and Madin-Darby bovine kidney cell lines, and thus it is used for vaccine production. The field isolates of FMDV could be passaged in BHK-21 clone 13 monolayer cell culture either in rawx or roller system, which showed a characteristic cytopathic effect (CPE) after adaptation to $5^{\text {th }}$ passages. Another way to virus propagation is the cell suspension as the BHK-21 is suspended in a media at which it is propagated. However, the cell culture system is laborious, time-consuming, and relatively low sensitive. It also requires careful handling of samples and a good biosafety measures [13].

Hence, This work was designed to compare between the effect of different cell culture systems including stationary system (rawx), roller culture systems and suspension system on the production of (FMDV) type A, O and SAT-2 so as to improve the potency of the FMD vaccine produced.

\section{Materials and Methods}

\section{Ethical approval}

The experiment was performed according to the protocol of Institutional Animal Ethics Committee, and the authors had taken permission of animal owners at the private farms.

\section{Animals}

17 native breed cattle from a farm in Sharkia Governorate, Egypt were found to be serologically negative for the presence of antibodies against FMDV type A, O or SAT-2 as proved by SNT and ELISA. These animals were used to determine the potency of the prepared vaccines.

\section{Virus serotypes}

FMDV serotypes (A IranO5, OPanAsia and SAT-2/Egypt 2012) were supplied by FMD research department, VSVRI were used and propagated twice in a primary monolayer of bovine kidney cells and then in BHK-21 monolayer cells through 6 serially passages.

\section{Stationary rawx and roller cell culture cultivation systems}

BHK monolayer cell cultures (BHK-21) clone 13 was obtained from the World Reference Lab. Pirbright Surrey, U.K. The cells were serially passage and maintained in the FMD Research Department, Veterinary Serum and Vaccine Research Institute, Abbasia, Cairo [14]. These cells were grown in rawx flasks as stationary system and in roller bottle as roller culture system. Minimum Essential Medium (MEM) modified with Hank's salt was supplied by Flow Laboratories, U.K. It was used as maintenance medium with $1-2 \%$ fetal calf serum added and was adjusted to $\mathrm{pH}$ 7.6-7.8 for the infected cell cultures at $37^{\circ} \mathrm{C}$. Inoculation of rawx and roller systems were inoculated separately with FMDV serotypes A, O and SAT-2.

\section{Suspension cell culture cultivation system}

BHK-21 clone 13 suspended cells from liquid nitrogen were suspended in complete growth media (especially contain fetal calf serum), where cell concentration was adjusted between 0.4 and $0.5 \times 10^{6}$ cells $/ \mathrm{ml}$. The Bellco bottle (vessel) was incubated at $36.5^{\circ} \mathrm{C}$ and good cell growth was indicated by an increase of $100 \%$ or more in cell number after $24 \mathrm{~h}$ incubation period. After $48 \mathrm{~h}$ of incubation, the viable cell number reached $2.0 \times 10^{6}$ cells $/ \mathrm{ml}$ or more if exponential growth has been maintained. When the concentration of cells reached for example $2.0 \times 10^{6}$ cells $/ \mathrm{ml}$ or more the cells either can be diluted to be cultivated again or centrifuged and resuspended in maintenance media (Hanks media) for cultivation of virus (virus inoculation). The cell number was determined by counting in "Modified Fuchs-Rosenthal" by using 0.05\% trypan blue as a vital stain [15]. Inoculation of bellco bottles were inoculated separately with FMDV serotypes A, $\mathrm{O}$ and SAT-2.

\section{Experimental design}

The $6^{\text {th }}$ BHK-21 passage of type A IranO5, OPanAsia and SAT-2/Egypt were inoculated separately on BHK-21 cells in roller bottles, rawx bottles and suspension bellco bottles using Multiplicity of Infection (MOI) as 1:100 according to Community Coordinating Institute Netherlands. Samples were obtained at 15, 18, 21 and $24 \mathrm{~h}$ post-virus inoculation. Samples were collected and freezed and thawed for three times and then kept at $-70^{\circ} \mathrm{C}$ (representing the total virus yield).

\section{FMDV purification}

Aseptically, the harvested culture medium from each FMDV serotype infected BHK-21 cell cultures were centrifuged in a cooling centrifuge at $7000 \mathrm{rpm}$ for $20 \mathrm{~min}$ to remove cell debris [16].

\section{FMDV serotypes concentration}

The purified tissue culture viral fluids of each serotype were concentrated by PEG-6000 to reach $1 / 10$ of its original volume [17].

\section{FMDV infectivity titration}

Titration of the obtained virus samples were carried out and CPEs of the virus was observed under an inverted microscope and processed for biological titration (TCID50) [18].

\section{Complement fixation test (CFT)}

It was carried out according to Health Protection Agency [19] to detect the virus antigenicity.

\section{Estimation of $146 \mathrm{~S}$ content of the FMDV serotypes}

The content of $146 \mathrm{~S}$ particles in prepared viral antigen estimated by using sucrose density gradient ultracentrifugation by determining the absorbance at $254 \mathrm{~nm}$ using ISCO 520C density gradient system according to Bartelling et al. [20]. 
Preparation of the trivalent FMD vaccine from the cultivation system with the highest antigenic virus yield

The trivalent FMD vaccine with Montanide ISA 206 were prepared according to Gamil [21] which are formed from the highest antigenicity virus serotypes harvested at $18 \mathrm{~h}$ post-inoculation from the different cell culture cultivation systems from the previously tested serotypes of O pan Asia-2, A Iran O5 and SAT-2/Egy/2012. Each of 5 cattle was inoculated as $3 \mathrm{ml}$ for each vaccine and Serum samples were collected pre-vaccination and every week until $4^{\text {th }}$ week, every 2 weeks for $16^{\text {th }}$ week, every 4 weeks until $32^{\text {nd }}$ week, and lastly, every 2 weeks until $42^{\text {nd }}$ week. Serum neutralization test was performed on the serum samples to detect the antibodies against serotypes $\mathrm{O}, \mathrm{A}$ and SAT-2 as described by Ferreira [22] and expressed as $\log _{10}$.Two cattle were left as a control negative along the experiment.

\section{Results and Discussion}

The main scope in vaccine production procedures is usually constructed in the production of a large amount of vaccine doses so as to fulfill the huge need of vaccine doses for different animals and also in addition to the potency of the produced vaccine regarding its high infectivity and antigenicity of the serotypes included in the vaccine.

As the BHK-21 cell line either the monolayer or the suspension systems are used in FMD vaccine production and to ensure the potency and the quality of the vaccine produced, It was of interest to follow-up the infectivity, complement fixing activity and $146 \mathrm{~S}$ content of FMDV type A, O and SAT-2/Egypt 2012 on BHK cell culture in roller, rawx and suspension culture systems. The FMDV serotypes A, O and SAT-2 were inoculated with an MOI (1:100).

The FMDV is characterized by its short eclipse phase as the virus can be detected after $3 \mathrm{~h}$ post-inoculation [23]. The virus increases in growth and multiplication on the BHK-21 and subsequently increases in its infectivity and antigenicity. In this study, the infectivity and antigenicity of the virus yield were examined at 15, 18, 21 and $24 \mathrm{~h}$ post-inoculation.

The virus titer yield from the different culture systems of cultivation including roller, rawx and suspension culture systems for serotype A, O and SAT-2 were detected at $15,18,21$ and $24 \mathrm{~h}$ post-inoculation as Figures-1-3, the results showed that there is difference in the titer between the different cultivation systems at all tested hours as the FMDV titer type A, O and SAT-2 obtained from the roller cultivation system showed the highest level followed by suspension cultivation system then the rawx cultivation system. The FMDV titer showed its highest level at $21 \mathrm{~h}$ post-inoculation in all the cultivation systems as at $21 \mathrm{~h}$ post-inoculation the FMDV titer was 8.1, 8.2, and 7.6 $\log _{10} \mathrm{TCID}_{50}$, respectively, for the roller system; as $6.3,6.3$, and 6.4 $\log _{10} \mathrm{TCID}_{50}$, respectively, for the suspension system;

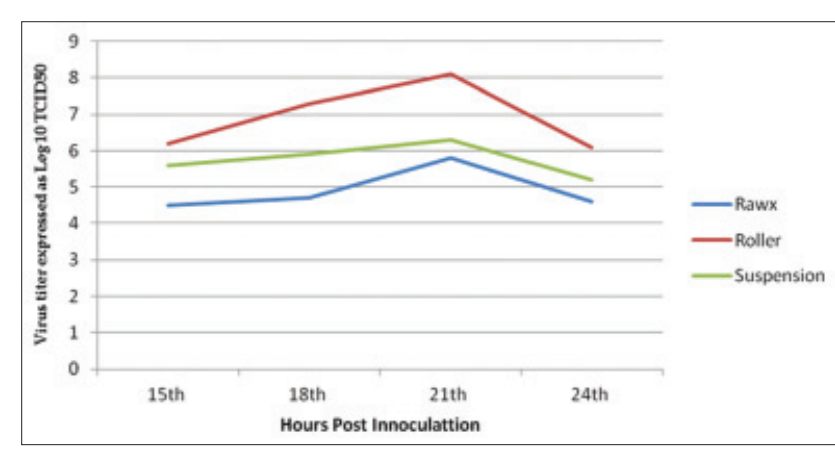

Figure-1: Effect of difference cell culture systems on foot and mouth disease virus serotype $(A)$ infectivity in baby hamster kidney-21 cell line at $37^{\circ} \mathrm{C}$.

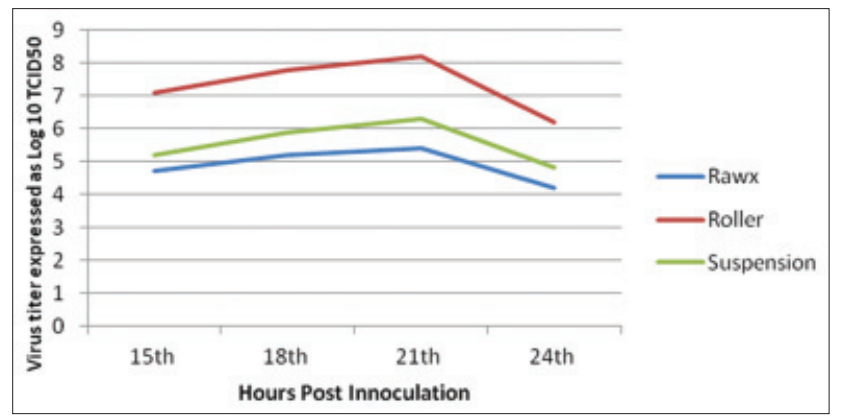

Figure-2: Effect of different cell culture systems on foot and mouth disease virus serotype $(\mathrm{O})$ infectivity in baby hamster kidney-21 cell line at $37^{\circ} \mathrm{C}$.

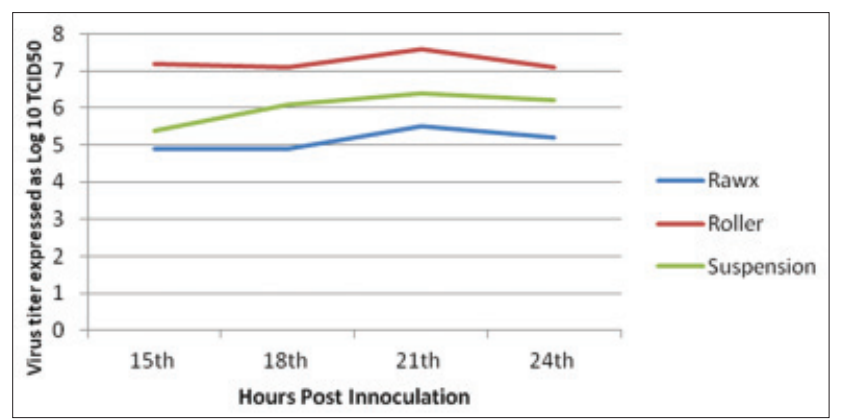

Figure-3: Effect of different cell culture systems on foot and mouth disease virus serotype (SAT-2) infectivity in baby hamster kidney-21 cell line at $37^{\circ} \mathrm{C}$.

and as 5.8, 5.4, and 5.5 $\log _{10} \mathrm{TCID}_{50}$, respectively, for the rawx cultivation system for the serotypes $\mathrm{A}, \mathrm{O}$, and SAT-2, respectively, and then decline at $24 \mathrm{~h}$ post-inoculation as the FMDV titer was 6.1, 6.2, and 7.1 $\log _{10}$ $\mathrm{TCID}_{50}$, respectively, for the roller system; as 5.2, 4.8, and 6.2 $\log _{10} \mathrm{TCID}_{50}$, respectively, for the suspension system; and as 4.6, 4.2, and 5.2 $\log _{10} \mathrm{TCID}_{50}$, respectively, for the rawx cultivation system for the serotypes A, O, and SAT-2, respectively. This finding is contributed to the result obtained by Ali et al. [23] who found that the highest infectivity for FMDV serotype A virus was achieved after $21 \mathrm{~h}$ post-inoculation. This difference in infectivity between the roller and rawx cultivation system may be attributed to the surface area difference between the rowx and roller cultivation systems as the rowx flasks has a $75 \mathrm{~cm}^{2}$ while the roller cultivation system has a surface area of $490 \mathrm{~cm}^{2}$ and subsequently the exposed area for growing cells 
is greater in the roller cultivation system and in agreement with Akram et al. [24] who found that the virus infectivity titer in the stationary monolayer of BHK21 cells in roller flask is higher than that in the rawx flasks and also agreed with Altaf et al. [25], Khawaja et al. [26], and Salivac et al. [27] who stated that the infectivity titer of the virus is directly proportional to number of BHK-21 cells in the culture system.

Depending on the fact reported by Ali et al. [23] that the protective capacity of FMD vaccine is the FMDV antigenicity; the FMDV yield from different cultivation systems must be tested and compared on their antigenicity by CFT and quantifying the $146 \mathrm{~S}$ intact virion content. The antigenicity detected by complement-fixing antibody titer (Table-1) showed that the highest titer was achieved by the roller cultivation system followed by the suspension and then the rawx cultivation system along all the tested hours post-inoculation and the highest complement fixing titer was achieved at $18 \mathrm{~h}$ post-inoculation for serotype A, O and SAT-2 1/64, 1/32, 1/64 for the roller system, respectively, and $1 / 32,1 / 16$ and $1 / 16$ for the suspension cultivation system for serotype $\mathrm{A}, \mathrm{O}$ and SAT-2, respectively, and $1 / 8$ for the rawx system for serotype A, O and SAT-2 This result come parallel with that obtained by quantifying the $146 \mathrm{~S}$ intact virion content as it reached its highest intact virion content at $18 \mathrm{~h}$ post-inoculation (Figures-4-6). The 146S intact virion content of serotype A, O and SAT-2 increases as it showed $4.3 \mathrm{ug} / \mathrm{ml}, 4 \mathrm{ug} / \mathrm{ml}$, and $4.2 \mathrm{ug} / \mathrm{ml}$ for the roller system, respectively, and $2.5 \mathrm{ug} / \mathrm{ml}, 2.7 \mathrm{ug} / \mathrm{ml}$, and $2.9 \mathrm{ug} / \mathrm{ml}$ for the suspension system, respectively, and $2.2 \mathrm{ug} / \mathrm{ml}, 2.2 \mathrm{ug} / \mathrm{ml}$, and $2.3 \mathrm{ug} / \mathrm{ml}$ for the rawx cultivation system, respectively.

Hence, from the previous results it was clear that the roller cultivation system showed the highest antigenicity (complement fixing antibody titer, 146S intact virion content) followed by the suspension and then the rawx cultivation system and the best time to harvest the virus is $18 \mathrm{~h}$ post-inoculation as it reached its highest level of antigenicity for the three cultivation systems. This comes in agreement with Ali [28] who found that $146 \mathrm{~S}$ content reached its maximum level by $18 \mathrm{~h}$ post-infection.

For making a confirmation between the pervious obtained results of the total virus yield from the different cultivation systems and the immune-protective effect against FMD, 3 montanide ISA 206 oil inactivated trivalent vaccines were prepared from the tested serotypes (A Iran O5. O Panasia and SAT-2/ EGY/2012) harvested at $18 \mathrm{~h}$ post-inoculation from the 3 culture systems. Tables- 2 showed the results of the mean antibody response come in a parallel manner with the previous results as the vaccine prepared from the roller cultivation system start its protective antibody titer at 2 weeks post-vaccination (WPV) as 1.62 against serotype A, 1.58 against serotype $\mathrm{O}$ and 1.68 against serotype SAT- 2 as the protection titer for FMD is $1.5 \log _{10}$ for SNT [29] while the vaccine

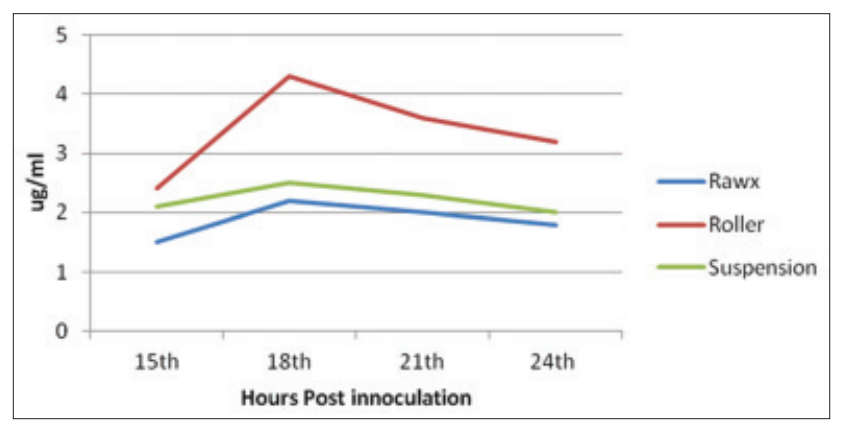

Figure-4: Effect of cell culture system on foot and mouth disease virus serotype (A) antigenicity (146S content) in baby hamster kidney-21 cell culture at $37^{\circ} \mathrm{C}$.

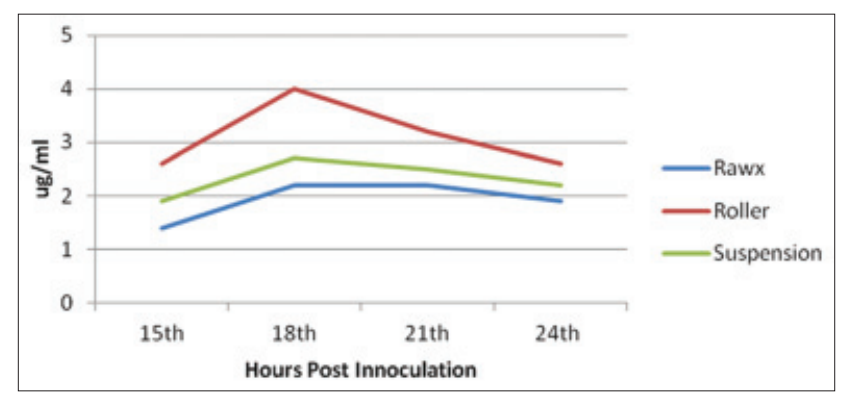

Figure-5: Effect of cell culture system on foot and mouth disease virus serotype $(0)$ antigenicity (146S content) in baby hamster kidney-21 cell culture at $37^{\circ} \mathrm{C}$.

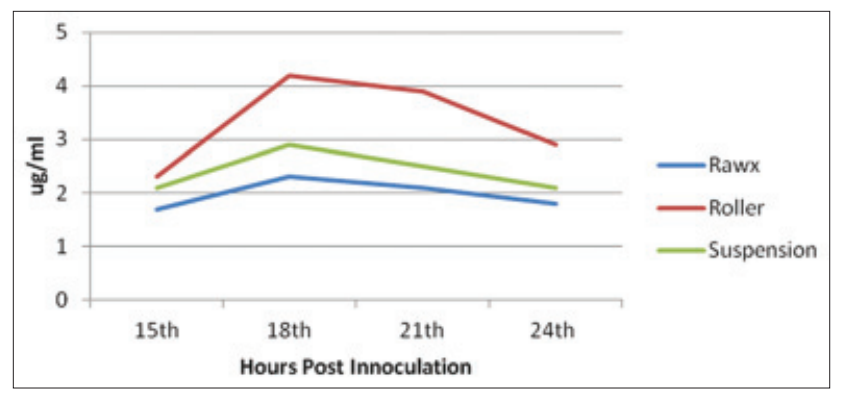

Figure-6: Effect of cell culture systems on foot and mouth disease virus serotype (SAT-2) antigenicity (146S content) in baby hamster kidney-21 cell line at $37^{\circ} \mathrm{C}$.

Table-1: Complement fixing titers of FMD virus serotypes using different cell culture systems.

\begin{tabular}{|c|c|c|c|c|c|c|c|c|c|}
\hline \multirow[t]{2}{*}{ HPI } & \multicolumn{3}{|c|}{ FMDV serotype (A) } & \multicolumn{3}{|c|}{ FMDV serotype $(0)$} & \multicolumn{3}{|c|}{ FMDV serotype (SAT-2) } \\
\hline & Rawx & Roller & Suspension & Rawx & Roller & Suspension & Rawx & Roller & Suspension \\
\hline $15^{\text {th }}$ & $1 / 4$ & $1 / 32$ & $1 / 16$ & $1 / 8$ & $1 / 32$ & $1 / 16$ & $1 / 4$ & $1 / 32$ & $1 / 16$ \\
\hline $18^{\text {th }}$ & $1 / 8$ & $1 / 64$ & $1 / 32$ & $1 / 8$ & $1 / 32$ & $1 / 16$ & $1 / 8$ & $1 / 64$ & $1 / 16$ \\
\hline $21^{\text {th }}$ & $1 / 8$ & $1 / 16$ & $1 / 8$ & $1 / 4$ & $1 / 16$ & $1 / 16$ & $1 / 4$ & $1 / 8$ & $1 / 8$ \\
\hline $24^{\text {th }}$ & $1 / 4$ & $1 / 8$ & $1 / 8$ & $1 / 4$ & $1 / 8$ & $1 / 8$ & $1 / 4$ & $1 / 4$ & $1 / 8$ \\
\hline
\end{tabular}

$\mathrm{HPI}=$ Hour post inoculation, FMDV=Foot and mouth disease virus 
Table-2: Tracing of FMD serum neutralizing antibody titer induced by the vaccines prepared by different culture systems.

\begin{tabular}{|c|c|c|c|c|c|c|c|c|c|}
\hline \multirow{3}{*}{$\begin{array}{l}\text { Vaccine } \\
\text { type } \\
\text { WPV }\end{array}$} & \multicolumn{9}{|c|}{ FMD serum neutralizing antibody titer $\left(\log _{10} / \mathrm{ml}\right)$} \\
\hline & \multicolumn{3}{|c|}{$\begin{array}{l}\text { Rawx cultivation } \\
\text { system vaccine }\end{array}$} & \multicolumn{3}{|c|}{$\begin{array}{l}\text { Roller cultivation } \\
\text { system vaccine }\end{array}$} & \multicolumn{3}{|c|}{$\begin{array}{l}\text { Suspension cultivation } \\
\text { system vaccine }\end{array}$} \\
\hline & $\begin{array}{c}\text { FMDV } \\
\text { serotype A }\end{array}$ & $\begin{array}{c}\text { FMDV } \\
\text { serotype } 0\end{array}$ & $\begin{array}{c}\text { FMDV } \\
\text { serotype } \\
\text { SAT-2 }\end{array}$ & $\begin{array}{c}\text { FMDV } \\
\text { serotype A }\end{array}$ & $\begin{array}{c}\text { FMDV } \\
\text { serotype } 0\end{array}$ & $\begin{array}{l}\text { FMDV } \\
\text { serotype } \\
\text { SAT-2 }\end{array}$ & $\begin{array}{c}\text { FMDV } \\
\text { serotype A }\end{array}$ & $\begin{array}{c}\text { FMDV } \\
\text { serotype } 0\end{array}$ & $\begin{array}{c}\text { FMDV } \\
\text { serotype } \\
\text { SAT-2 }\end{array}$ \\
\hline 0 & 0.25 & 0.35 & 0 & 0.506 & 0.4 & 0.51 & 0.546 & 0.6 & 0.76 \\
\hline 1 & 0.9 & 0.76 & 0.42 & 1.196 & 0.926 & 1.02 & 1.296 & 1.22 & 1.09 \\
\hline 2 & 1.23 & 1.34 & 0.96 & 1.62 & 1.58 & 1.68 & 1.43 & 1.39 & 1.31 \\
\hline 3 & 1.51 & 1.57 & 1.53 & 1.69 & 1.7 & 1.8 & 1.53 & 1.56 & 1.6 \\
\hline 4 & 1.62 & 1.65 & 1.69 & 1.79 & 1.75 & 1.96 & 1.74 & 1.68 & 1.78 \\
\hline 6 & 1.69 & 1.71 & 1.8 & 1.81 & 1.8 & 2.13 & 1.89 & 1.76 & 1.89 \\
\hline 8 & 1.75 & 1.83 & 1.9 & 1.89 & 1.92 & 2.35 & 2.06 & 1.87 & 2.15 \\
\hline 10 & 1.82 & 1.92 & 1.96 & 2.25 & 2.4 & 2.49 & 2.18 & 1.96 & 2.21 \\
\hline 12 & 1.79 & 1.86 & 1.72 & 2.6 & 2.69 & 2.56 & 2.25 & 2.13 & 2.38 \\
\hline 14 & 1.61 & 1.72 & 1.61 & 2.73 & 2.82 & 2.67 & 2.1 & 2.04 & 2.1 \\
\hline 16 & 1.52 & 1.6 & 1.58 & 2.54 & 2.7 & 2.47 & 1.8 & 1.86 & 1.86 \\
\hline 20 & 1.43 & 1.43 & 1.47 & 2.25 & 2.56 & 2.3 & 1.69 & 1.63 & 1.7 \\
\hline 24 & 1.36 & 1.31 & 1.4 & 2.15 & 2.3 & 2.19 & 1.53 & 1.57 & 1.62 \\
\hline 28 & 0.96 & 1.2 & 1.31 & 1.93 & 2.15 & 2.05 & 1.35 & 1.48 & 1.36 \\
\hline 32 & 0.42 & 0.35 & 1.2 & 1.82 & 1.93 & 1.94 & 1.23 & 1.3 & 1.25 \\
\hline 34 & ND & ND & 0.59 & 1.68 & 1.71 & 1.83 & 1.06 & 1.23 & 1.06 \\
\hline 36 & ND & ND & ND & 1.58 & 1.67 & 1.7 & 0.94 & 1.06 & 0.65 \\
\hline 38 & ND & ND & ND & 1.35 & 1.3 & 1.48 & ND & 0.87 & ND \\
\hline 40 & ND & ND & ND & 1.21 & 1.15 & 1.3 & ND & ND & ND \\
\hline 42 & ND & ND & ND & 0.92 & 0.96 & 1.18 & ND & ND & ND \\
\hline
\end{tabular}

$\mathrm{WPV}=$ Week post-vaccination, $\mathrm{FMD}=$ Foot and mouth disease, $\mathrm{ND}=$ Not detected, FMDV=Foot and mouth disease virus

prepared from the suspension cultivation system start its protective antibody titer at $3 \mathrm{WPV}$ as 1.53 against serotype $\mathrm{A}, 1.56$ against serotype $\mathrm{O}$ and 1.6 against serotype SAT-2 and the vaccine prepared from the rawx cultivation system start its protective antibody titer at $3 \mathrm{WPV}$ as 1.51 against serotype A, 1.57 against serotype $\mathrm{O}$ and 1.53 against serotype SAT-2. The immune protection period varies between the different vaccines as it lasts for $36 \mathrm{WPV}$ for the roller cultivation system vaccine while it lasts for $24 \mathrm{WPV}$ for the suspension cultivation vaccine and it lasts for $16 \mathrm{WPV}$ for the rawx cultivation system vaccine.

\section{Conclusion}

It is clear that the best cultivation system used for production of FMD vaccine regarding its infectivity and antigenicity is the roller cultivation system as it induce the highest titer and antigenicity either in the complement fixing titer or the $146 \mathrm{~S}$ content among the other two types and that is reflected on the antibody titer and the protection period in vaccinated cattle.

\section{Authors' Contributions}

Amr Ismail has prepared the three tissue culture systems; prepare and inoculate the three foot and mouth disease virus serotypes; detect the infectivity of the FMDV by virus titration and the antigenicity by CFT and quantifying the 146S content; inactivate the virus yield; formulate the different vaccine; carry out the SNT and ELISA tests for antibody detection against FMD; wrote the manuscript and follow up the steps of publication.

\section{Acknowledgments}

The authors are thankful to Prof. Dr. Sayed Zeidan Director of VSVRI, Prof. Dr. Manal Awad Deputy of VSVRI and all members of FMD department specially Prof. Dr. Abu Bakr Aggour head of FMD department, VSVRI. Furthermore, deep thanks to Prof. Dr. Mohamed Hassan Khoudier, for reviewing this work. This work was funded by VSVRI, Abbasia, Cario, Egypt.

\section{Competing Interests}

The authors declare that they have no competing interests.

\section{References}

1. Depa, P.M., Dimri, U., Sharma, M.C. and Tiwari, R. (2012) Update on epidemiology and control of foot and mouth disease - A menace to international trade and global animal enterprise. Vet. World, 5(11): 694-704.

2. Longjam, N., Deb, R., Sarmah, A.K., Tayo, T., Awachat, V.B. and Saxena, V.K. (2011) A brief review on diagnosis of foot and- mouth disease of livestock: Conventional to molecular tools. Vet. Med. Int., 2011: 905768.

3. Rowland, R. (2003) Foot and Mouth Disease. Elsevier Australia. p1.

4. Grubman, MJ, and Baxt, B. (2004) Foot-and-mouth disease. Clin. Microbiol. Rev., 17: 465-493.

5. Guzman, E., Taylor, G., Charleson, B., Skinner, M.A. and Ellis, S.A. (2008) An MHC restricted CD8+ T-cell response is induced in cattle by Foot-and-mouth disease virus (FMDV) infection and also following vaccination with inactivated FMDV. J. Genviro 1., 89: 667-675.

6. Aidaros, H.A. (2002) Regional status and approaches to control and eradication of FMD in the Middle East and North Africa. Rev. Sci. Tech. Off. Int. Epizoot., 21(3): 451-458. 
7. Farag, M.A., Aggour, M.A. and Daoud, A.M. (2005) ELISA as a rapid method for detecting the correlation between the field isolates of Foot and Mouth Disease and the current used vaccine strain in Egypt. Vet. Med. J. Giza. Vol., 53(4): 949-955.

8. Parida, S. (2009) Vaccination against foot-and-mouth disease virus: Strategies and effectiveness Expert Rev. Vaccines, 8(3): 347-365.

9. Abd El- Rahman, A.O., Farag, M.A., El- Kilany, S., Ali, S.M. and Yazed, M.A. (2006) Isolation and Identification of Serotype O of Foot and Mouth Disease Virus from Imported Bulls and its Correlation to the Current used Vaccine Strain O1/3/1993. Proceeding $3^{\text {rd }}$ International Conference Veterinary Research Division, NRC, Cairo, Egypt. p91-100.

10. Abd El-Aty, S.M., Hiam, M.F., Hind, M.D., El-Sayed, E.I., Wael Mossad, G., Rizk, S.A., Abu-El-Naga, H., Mohamed, A.A., El-Kreem, A.A. and Farouk, E.M. (2013) Isolation and molecular characterization of foot and mouth disease SAT2 virus during outbreak 2012 in Egypt. J. Vet. $A d v ., 3(2):$ 60-68.

11. Gamal, W.M., Soliman, E.M.M. and El-Manzalawy, M.A. (2014) Tracing the antibody mediated acquired immunity by foot and mouth disease and rift valley fever combined vaccine in pregnant ewes and their lambs. Vet. World, 7(11): 922-928.

12. Abd El-Karim, A.S., Ebeid, M.H.B., Ibrahim, F.K. and Azab, A.M. (2011) Field application of bivalent inactivated foot and mouth disease vaccine adjuvanted by ISA 206. $4^{\text {th }}$ Science Conference, Al-Kasr 25-28 May, 2011. Benha Vet. Med. J., Special Issue(1):82-87.

13. Neeta, L., Rajib, D., Sarmah, A.K., Tilling, T., Awachat, V.B. and Saxena, V.K. (2011) A brief review on diagnosis of foot-and-mouth disease of livestock: Conventional to molecular tools. Vet. Med. Int., 2011: Article ID 905768. DOI:10.4061/2011/905768.

14. Huang, X., Yong, L., Hui, F. and Congyi, Z. (2011) Establishment of persistent infection with foot and mouth disease virus in BHK-21 cells. Virol. J., 8: 169

15. Guo, H.C., Jin, Y., Han, S.C., Sun, S.Q., Wei, Y.Q., Liu, X.J., Feng, X., Liu, D.X., Liu, X.T. (2015) Quantitative proteomic analysis of BHK-21 cells infected with footand-mouth disease virus serotype Asia 1. PLoS One, 10(7): e0132384.

16. Daoud, H.M., Ibrahim, E.E., El-Din, W.M.G., Hassanin, A.I.H. (2013) Preparation of foot and mouth disease trivalent vaccine type A, O, SAT2 and determination of the Guinea pig protective dose 50 (GPPD). Vet. World, 6(11): 844-851.

17. Shabana, W. (2014) Preparation of combined oil vaccine against foot and mouth disease and rift valley fever in sheep.
Ph.D. Faculty of Veterinary Medicine, Cairo University.

18. Alhaji, S. (2011) A modified arithmetical method of Reed and Muench for determination of a relatively ideal median lethal dose LD50. Afr. J. Pharm. Pharmacol., 5(12): 1543-1546.

19. Health Protection Agency. (2009) Complement Fixation Tests. Issue no: 3 Issue date 11.12.09. Issued by: Standards Unit, Department for Evaluations, Standards and Training. $1-23$.

20. Bartelling, A.S.J., Van Maanan, C., Yadin, H. and Anemaet, D.A.J. (1990) A foot and mouth disease vaccine bank; purified inactivated antigen stored at ultra-low temperatures for the rapid preparation of double oil emulsion vaccines. European Commission for Control of Foot and Mouth Disease. Session of Research Group of the Standing Technical Committee, Lindholm. p172-177.

21. Gamil, M.A. (2010) Studies on the immune response of calves vaccinated inactivated bivalent FMD virus vaccine type O/1 and A/Egypt 2006. MVSC in Veterinary Science (Virology). Benha University.

22. Ferreira, M.E.V. 1976. Microtitre neutralization test for the study of FMD antibodies. Bol. Centro Pan Americano de Fiebre aftosa 21: 22-23.

23. Ali, S.M., Ismail, A.H., Soliman, E.M. and Mostafa, H.A. (2013) Studies on growth kinetics of the FMDV serotype SAT-2 Egyptian strain in cell culture. J. Vet. Adv., 3(2): 92-97.

24. Akram, Q., Muhammad, K., Rabbani, M., Nazir J., Nawaz, M., Hanif, K. and Shakoor, Z. (2013) Augmentation of biological titer of foot and mouth disease virus in in vitro cultures. J. Anim. Plant Sci., 23(3): 771-774.

25. Altaf, I., Saddique, M., Irshad, M., Khan, M.Z., Anjum, A.A. and Kamran, M. (2012) Antibody response of rabbits to combined hemorrhagic septicemia and foot and mouth disease virus vaccine. J. Anim. Plant Sci., 22(2): 501-504.

26. Khawaja, R.M., Muhammad, K., Shahzad, W., Hussain, I., Choudhry, Z.I., Awan, F.N., Bukhari, A., Altaf, I. and Hanif, A. (2009) Isolation, adaptation and sero-typing of local strains of foot and mouth disease virus Pakistan. J. Zool., 9: 173-177.

27. Salivac, I., Srček, V.G., Radošević, K., Kmetič, I. and Kniewald, Z. (2006) Aujeszky's disease virus production in disposable bioreactor. J. Bio sci., 31: 363-368.

28. Ali, S.M. (2009) Kinetic studies on the sensitivity and susceptibility of BHK21 cells to replication of FMD Serotype (A) Isolated from Egypt Outbreak 2006. $6^{\text {th }}$ Science Conference of Mansoura, Faculty of Mansoura. p929-938.

29. OIE. (2013) OIE/FAO Foot-and-Mouth Disease Reference Laboratory Network, Annual Report 2013. 